\title{
The Comparative Effectiveness of Phaleria macrocarpa (Scheff.) Boerl. Pericarp Ethanol Extract and Metformin in Reducing Blood Sugar Levels and Ameliorating the Langerhans Islets Degeneration in Diabetic Rat Models
}

\author{
Perbandingan Efektivitas Ekstrak Buah Mahkota Dewa dan Metformin \\ terhadap Kadar Gula Darah dan Perbaikan Pulau Langerhans \\ Tikus Model Diabetes
}

\author{
Eman Sutrisna ${ }^{1 *}$, Qurrotu 'Aini ${ }^{1}$, Ika Murti Harini ${ }^{1}$, Nur Signa Aini Gumilas ${ }^{1}$, \\ Mustofa $^{1}$, Evy Sulistyoningrum ${ }^{2}$ \\ ${ }^{1}$ Faculty of Medicine, Jenderal Soedirman University \\ Jalan Dr. Gumbreg No 1, Purwokerto 53112, Indonesia \\ ${ }^{2}$ Faculty of Medicine, Indonesian Islamic University \\ Jalan Kaliurang, Sleman 55584, Indonesia \\ *Corresponding author email: rahma24sutrisna@gmail.com
}

Received 25-01-2020

Accepted 10-07-2020

Available online 30-07-2020

\begin{abstract}
Phaleria macrocarpa (Scheff.) Boerl. has been widely used in the treatment of diabetes mellitus but its effectiveness is still inconclusive so it needs to be compared with standard drugs such as metformin. This study aims to analyze the effects of $P$. macrocarpa fruit extracts on blood sugar levels and the repairing of the pancreatic Langerhans islets of diabetic rat models. The study was conducted experimentally by pre and post-test design with a control group. Thirty white rats were divided into 6 groups. All rats were treated with $40 \mathrm{mg} / 200 \mathrm{~g} \mathrm{BW}$ of streptozotocin (STZ) to induce hyperglycemia, except group I. Group II as a negative control was given with aquadest. Group III, IV, and V were given with ethanol extract of $P$. macrocarpa pericarps at doses of 200,250 , and $300 \mathrm{mg} / 200 \mathrm{~g}$ BW/day, respectively. Group VI was given with metformin at a dose of $150 \mathrm{mg} / 200 \mathrm{~g} \mathrm{BW} /$ day. On the $22^{\text {nd }}$ day of treatment, blood specimens were taken for examination of fasting blood sugar levels and pancreatic organs were analyzed for histopathological examination of the islets of pancreatic Langerhans. The data were statistically analyzed with $\alpha<0.05 ; \mathrm{Cl} 195 \%$. Paired sample ttest results showed a significant decrease in blood sugar levels before and after treatment in group $V(p$-value $=0.048)$. One way anova and post hoc Least Significant Difference (LSD) test results showed a significant difference in mean blood sugar levels after the final treatment between groups I and II ( $p$-value=0.013), I and III (pvalue $=0.004)$, I and IV (p-value=0.002), I and VI ( $p$-value $=0.000)$, II and VI (pvalue $=0.031$ ), and $V$ with VI (p-value $=0.005)$; one way anova and post hoc LSD test results showed a significant difference in the mean area of islets of pancreatic
\end{abstract}


Langerhans between group I and all treatment groups ( $p$-value $=0.000)$, II with $\mathrm{V}$ and $\mathrm{VI}$ ( $p$-value $=0.000$ and 0.009$)$, III with $V$ and $V I$ ( $p$-value $=0.000$ and 0.001$)$, and IV with $V(p$ value $=0.003$ ). It can be concluded that the extract of $P$. macrocarpa pericarps showed a hypoglycemic effect and repaired the damage in Langerhans islets of STZ-induced rat in a dose-dependent manner.

Key words: blood sugar, diabetic model, Langerhans islets, Phaleria macrocarpa (Scheff.) Boerl., streptozotocin.

\section{Introduction}

Diabetes mellitus (DM) is still a health problem in the world and is one of the five main causes of death (Erejuwa et al., 2011; WHO, 2016). In 2012, diabetes caused 1.5 million death in the world (WHO, 2016). The number of DM patients in the world is estimated to continue to increase to 592 million by 2035. Indonesia is ranked seventh with the highest prevalence of DM in the world with the number of people who live in diabetes expected to reach more than 14.1 million in 2035 (International Diabetes Federation, 2013).

DM is a serious chronic metabolic disease due to damage to the pancreas so that it cannot produce enough insulin and also due to the body's inability to use insulin (insulin resistance). This condition will cause an increase in blood sugar levels, which is called hyperglycemia. Persistent hyperglycemia triggers an increase in Reactive Oxygen Species (ROS) which induces excessively increase in free radicals. Excessive free radicals cause oxidative stress and cause damage to $\beta$ cells in the islets of Langerhans (Novelli et al., 2014). Damage of betha-cells results in reduced clusters of $\beta$ cells that cause atrophy at the size of the islets of Langerhans. The decrease in size (atrophy) of the islets of Langerhans reaching $60 \%$ of volume which can also stimulated by the insulin hypersecretion due to insulin resistance which cause increasing of insulin need. Hypersecretion of insulin increases endoplasmic and mitochondrial reticulum activity which ultimately increases free radical accumulation. (Judiono et al., 2009; Jones et al., 2010).

Significant changes in the histological structure of the islets of Langerhans are one of the typical pathological features and are often found in patients and animal models of diabetes. These changes occur due to glucotoxicity due to chronic hyperglycemia in the $\beta$ cells of the islets of Langerhans, which occur both quantitatively (atrophy of the islets of Langerhans), and qualitatively (necrosis, degeneration, and amyloidosis) (Suarsana et al., 2010). On pancreatic histological examination, the size of the Langerhans islests can be expressed in terms of diameter, area, and volume.

Until now, metformin is still a mainstay drug in the treatment of diabetes, especially type-2 DM. 
Metformin is a class of biguanide drugs that are believed to improve insulin sensitivity, increase peripheral glucose use, and reduce glucose release from the liver (Bjornstad et al., 2018; CreeGreen et al., 2019). Metformin can prevent glucotoxicity and reduce oxidative stress due to free radical formation (Zhou et al., 2018). The combination of metformin and Lcysteine have been shown to suppress insulin resistance in streptozotocininduced type 2 diabetic rats, while in monotherapy, metformin shown ability to significantly reduce oxidative stress, serum free fatty acids (FFAs) levels, and inflammatory markers, caspase-3, and cytochrome c levels which can inhibit cells apoptosis (Salman et al., 2013). Murad et al. (2015) showed that metformin could increase regeneration of Langerhans islets and reduce oxidative stress in Sprague Dawley rats with diabetes models.

Phaleria macrocarpa (Scheff.) Boerl. is an herbal medicine that has been widely used by the people of Indonesia as an anti-diabetes drug. The compounds contained in $P$. macrocarpa fruit include tannin, terpenoids, hydroxy benzophenone glucoside, alkaloids, flavonoids, saponins, and polyphenols (Hendra et al., 2011). Alkaloids, saponins, and flavonoids are compounds that have antioxidant effects. Arjadi and Priyo's research (2010) shows that the giving of diced flesh of $P$. macrocarpa can regenerate Langerhans island $\beta$ cells which is marked by an increase in the average number of Langerhans island $\beta$ cells and an increase in Langerhans island diameter. Antioxidants effect of flavonoids can protect the islets of Langerhans from free radicals while the alkaloids have the ability to regenerate damaged Langerhans islet $\beta$ cells (Arjadi \& Priyo, 2010).

However, until now the effectiveness of the extract of $P$. macrocarpa fruit has not been tested as an anti-diabetes drug that can be aligned to other anti-diabetic drugs that have long been used. Therefore, this study aims to analyze the anti-diabetic effectiveness of the extract of $P$. macrocarpa pericarps compared to metformin as a standard drug. The effectiveness was evaluated based on its ability to re-reduce fasting blood sugar levels and repair pancreatic damage that be seen from the alteration of area of Langerhans islets after treatment in rat of diabetes models induced by streptozotocin (STZ).

\section{Materials and Methods}

General

This research was conducted experimentally by pre and post-test with control group design. All of the research procedures have been approved by the Medical and Health Research Committee (MHREC) Faculty of Medicine, Gadjah Mada University.

Material and Instrument

This study used materials such as solvent of $96 \%$ ethanol, $1 \%$ carboxymethyl cellulose (CMC), metformin $\mathrm{HCl} 500 \mathrm{mg}$ (Forbetes 500 ${ }^{\circledR}$ ), 
streptozotocin (STZ), reagent of GODPAP, ether, solution of Mayer's hematoxylin-eosine, $\quad$ xylol and $10 \%$ phosphate buffer saline (PBS). While, instruments used include centrifuges (Kubota ${ }^{\circledR}$ ), water tube, spectrophotometer (Optima ${ }^{\circledR} \mathrm{Sp} 300$ ), micropipette $(10 \mu \mathrm{L}$ and $1000 \mu \mathrm{L})$, portable digital scales (Nagata ${ }^{\circledR}$ Type Lcs 12), multihead microscopes (Nikon $^{\circledR}$ Eclipse $\mathrm{Ci}-\mathrm{L})$ with software CellSense Standard ${ }^{\circledR}$, microscopes (Motic $^{\circledR} \quad$ B2 Series), Optilab ${ }^{\circledast}$, and minor surgical tools.

\section{Research Courses}

1. Plant extraction

P. macrocarpa fruit were obtained from Merapi Herbal Farma, Yogyakarta, Indonesia and authenticated at Laboratory of Taxonomy Faculty of Biology, Jenderal Soedirman University. $P$. macrocarpa pericarps was extracted with $96 \%$ ethanol using maceration techniques. The flesh of $P$. macrocarpa fruit is washed, thinly sliced and dried in the sun but covered with a black cloth to keep the active ingredients in control. $P$. macrocarpa pericarps that has dried mashed into powder. Fifty grams of powder was extracted in $500 \mathrm{~mL}$ 96\% ethanol by maceration (72 h) Then, using a rotary vacuum evaporator to vaporize the remaining ethanol $96 \%$ solvent and then the extract is dried in a water-bath at a temperature of 60-70 ${ }^{\circ} \mathrm{C}$ until it thickens into a paste (Singh, 2008).
2. Animal and experimental protocol

Rats were obtained from the Laboratory of Pharmacology, Faculty of Medicine, Padjadjaran University, Bandung. The rats were housed in wire cages at $25-27{ }^{\circ} \mathrm{C}$ and were adaptated for a week at Pharmacology Laboratory. Thirty of healthy rats weighing between about 150-200 g and 2-3-month age were divided in to 6 groups. All rats were induced with $40 \mathrm{mg} / 200 \mathrm{~g}$ BW of streptozotocin (STZ) to experience hyperglycemia, except group I. Group I as a healthy control were given routin care. Group II as a negative control were given aquadest. Group III, IV, and V were given the ethanol extract of $P$. macrocarpa pericarps with doses of 200, 250, and 300 $\mathrm{mg} / 200 \mathrm{~g}$ BW/day, respectively. Group VI was given metformin at a dose of $150 \mathrm{mg} / 200 \mathrm{~g}$ BW/day. On the $22^{\text {nd }}$ day of treatment, blood specimens were taken for examination of fasting blood sugar levels and pancreatic organs for histopathological examination of the islets of Langerhans.

3. Blood sugar examination

The blood sugar levels check is carried out using the GOD-PAP method with the following procedure. The reagent blank is measured. A standard solution is prepared by mixing $2 \mathrm{~mL}$ of reagent and $0.2 \mathrm{~mL}$ standard in a test tube, after the color turns purplish red, the standard solution is incubated at a temperature of $20-25{ }^{\circ} \mathrm{C}$ for 10 
minutes and then, measuring the absorbance using a spectrophotometer at a wavelength of $546 \mathrm{~nm}(492-550 \mathrm{~nm})$. A sample solution is further prepared by mixing 2 mLof reagent and $0.2 \mathrm{~mL}$ of sample (serum) into a test tube and incubating for 10 minutes at a temperature of $20-25{ }^{\circ} \mathrm{C}$. The absorbance is measured by using a spectrophotometer at a wavelength of $546 \mathrm{~nm}$ (492-550 nm). Blood sugar levels are determined according to the formula (Subiyono et al., 2016):

Blood glucose level $(\mathrm{mg} / \mathrm{dL})=$ (sample absorbance/standard absorbance) $x$ standard concentration

4. Histopathological techniques

The pancreas organ is fixed with $10 \%$ buffered formalin for 48 hours, be continued dehydration of the specimens in multilevel concentration of ethanol, cleared in xylene and the process of embedding into paraffin. After freeze, the paraffin blocks were cut using a microtome with a thickness of $5 \mu \mathrm{m}$ and put into a water bath with a temperature of 42 $45{ }^{\circ} \mathrm{C}$ and dried. Then, stained with hematoxyline and eosin ( $\mathrm{H}$ and $\mathrm{E})$. The histological slides are examined under the light microscope which connected to the CellSense Standard ${ }^{\circledR}$ software for measuring the large of langerhans islets area at 200x magnification. The large of Langerhans islets area was obtained from the average large of five Langerhans islets areas of each slide. The repairing of the Langerhans islets was determined based on the average area of the Langerhans island in each study group (Guido et al., 2011).

5. Statistical analysis

The differences of blood sugar between pre-test and post-test were tested with paired sample t-test while the differences of blood sugar and the large of Langerhans islets area among groups of the study were tested with one-way anova test followed by post hoc test (LSD).

\section{Results and Discussion}

The blood sugar level was measured use GOD-PAP method by spectrophotometer at a wavelength of $546 \mathrm{~nm}$. The data in Table 1. show the information of the average of blood sugar levels among groups of the study since initial condition (before induction), after induction (pre-test) and after treatment (post-test). All groups have an average of normal initial blood sugar levels (107.40-116.00 $\mathrm{mg} / \mathrm{dL})$ and increased more than normal after induction by given streptozotocine (206.73-357.8 mg/dL). The normal fasting blood sugar levels of rat is $108.55 \pm 7.58-122.3 \pm 16.28 \quad \mathrm{mg} / \mathrm{dL}$ (Sihombing, 2011). So, diabetic rat models can be made establishly in this study. 
Table 1. The average of blood sugar levels among groups of the study

\begin{tabular}{lccc}
\hline \multirow{2}{*}{ Groups of Study } & \multicolumn{3}{c}{ Mean of Blood Sugar Levels (g/dL) } \\
\cline { 2 - 4 } & Initial & Pre-Test & Post-Test $^{\mathbf{b}}$ \\
\hline $\mathbf{I}^{\mathbf{a}}$ & $111.80 \pm 7.95$ & $83.40 \pm 18.43$ & $99.00 \pm 16.26$ \\
$\mathbf{I I}^{\mathbf{a}}$ & $116.00 \pm 2.83$ & $302.80 \pm 110.88$ & $252.40 \pm 122.75$ \\
$\mathbf{I I I}^{\mathbf{a}}$ & $112.20 \pm 2.49$ & $336.20 \pm 21.12$ & $282.80 \pm 103.94$ \\
$\mathbf{I V}^{\mathbf{a}}$ & $107.40 \pm 16.86$ & $206.73 \pm 89.45$ & $297.00 \pm 111.27$ \\
$\mathbf{V}^{\mathbf{a}}$ & $113.40 \pm 6.23$ & $344.20 \pm 72.11$ & $205.20 \pm 78.41^{*}$ \\
$\mathbf{V I}^{\mathbf{a}}$ & $114.20 \pm 5.76$ & $357.80 \pm 41.57$ & $384.60 \pm 70.25$ \\
\hline
\end{tabular}

Note: ${ }^{a}=$ Paired sample t-test; ${ }^{*}=p$-value $<0.05,{ }^{b}=$ one way anova and post hoc LSD test, ${ }^{*}=p$ value $<0.05$ vs group $\mathrm{VI}$, group I=healthy control, group II/negative control=diabetic models+aquadest, group $\mathrm{III}=$ diabetic models+ethanol extract of $P$. macrocarpa pericarps $200 \mathrm{mg} / 200 \mathrm{~g} \mathrm{BW} /$ day, group IV=diabetic modelstethanol extract of $P$. macrocarpa pericarps $250 \mathrm{mg} / 200 \mathrm{~g} \mathrm{BW} /$ day, group $\mathrm{V}=$ diabetic modelstethanol extract of $P$. macrocarpa pericarps $300 \mathrm{mg} / 200 \mathrm{~g}$ BW/day, group VI=diabetic models+metformin 150 $\mathrm{mg} / 200 \mathrm{~g}$ BW/day.

The effect of the extract of $P$. macrocarpa pericarps on blood sugar levels showed that the extract can decrease blood sugar levels between pre-test (before treatment) and posttest (after treatment), as showed in Figure 1. The highest decreasing of blood sugar levels occurs in group $V$ which treated with the $P$. macrocarpa fruit extract dose $300 \mathrm{mg} / 200 \mathrm{~g}$ BW/day. Statistical analysis by using paired sample t-test showed that there is significantly differences of blood sugar levels between pre-test and post test, specially in group $\mathrm{V}(\mathrm{p}$-value $=0.048 ; \mathrm{Cl}$ $95 \%)$, but were not significantly differences in another groups ( $p$ value $>0.05 ; \mathrm{Cl} 95 \%$ ), include in group $\mathrm{VI}$ which treated with metformin.

Among groups of the study, the group $V$ has a lowest of blood sugar levels, even when was compared to group VI statistically there was significant difference of blood sugar levels between a both groups ( $p$ - value $=0,005 ; \mathrm{Cl} 95 \%)$. This result show that $P$. macrocarpa fruit extract dose 300 $\mathrm{mg} / 200 \mathrm{~g}$ BW/day more effective than metformin dose $150 \mathrm{mg} / 200 \mathrm{~g}$ BW/day decrease to blood sugar levels on diabetic rat models.

It was possible that this result occurs due to the content of the active compounds of $P$. macrocarpa fruit extract, such as tannin, terpenoids, hydroxy benzophenone glucoside, alkaloids, flavonoids, saponins, and polyphenols which are suspected to have hypoglycemic (Hendra et al., 2011). Alkaloids, saponins, and flavonoids are compounds that have antioxidant and antihyperglycemic effects (Ali et al., 2012; Kumar et al., 2011). In addition, the extract of $P$. macrocarpa pericarps has $\alpha$-glucosidase inhibitors compound that work to inhibit the enzymes hydrolase, pancreatic $\alpha$-amylase, and other intestinal enzymes such as isomaltase, maltase, and sucrose. These enzymes will hydrolyze carbohydrates 
which are broken down into glucose and other monosaccharides, thereby reducing glucose absorption from the intestine and eventually decreasing blood glucose levels (Sugiwati et al., 2006).

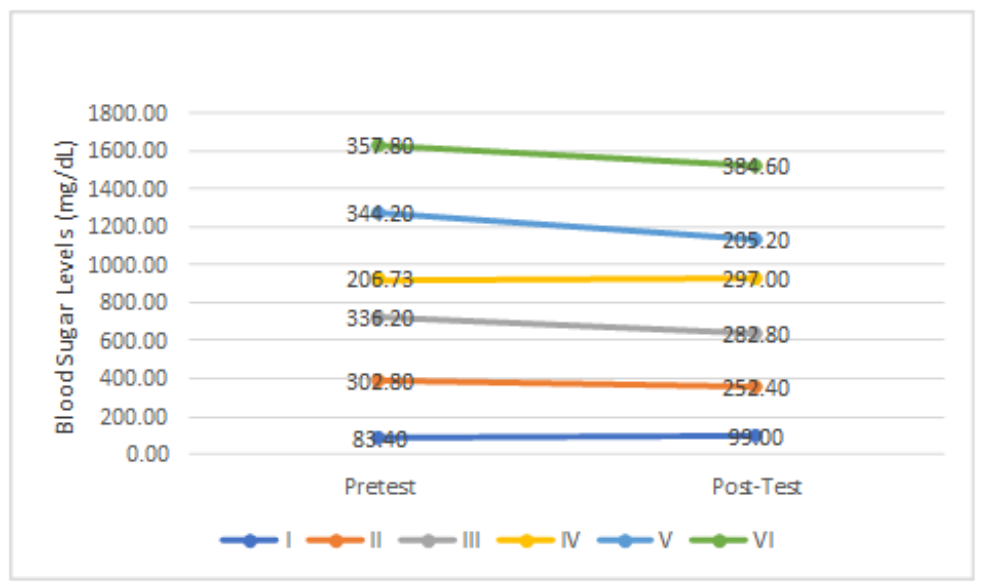

Figure 1. Comparison of blood sugar levels between pre-test and post-test; group I=healthy control, group II/negative control=diabetic models+aquadest, group III=diabetic models+ethanol extract of $P$. macrocarpa pericarps 200 $\mathrm{mg} / 200 \mathrm{~g}$ BW/day, group IV=diabetic models+ethanol extract of $P$. macrocarpa pericarps $250 \mathrm{mg} / 200 \mathrm{~g}$ BW/day, group $\mathrm{V}=$ diabetic models+ethanol extract of $P$. macrocarpa pericarps $300 \mathrm{mg} / 200 \mathrm{~g} \mathrm{BW} /$ day, group $\mathrm{VI}=$ diabetic models+metformin $150 \mathrm{mg} / 200 \mathrm{~g} \mathrm{BW/day.}$

Other mechanisms of the effects of $P$. macrocarpa fruit extract so that it can significantly reduce blood sugar levels occur through effects that increase blood glucose transport into cells, stimulate glycogen synthesis and inhibit glucose synthesis by inhibiting the enzyme 6-phosphatase, fructose 1,6bisphosphatase, and increase glucose oxidation through glucose 6-phosphate dehydrogenase. Inhibition of these enzymes will reduce glucose formation from non-carbohydrates substrates (Arjadi \& Priyo, 2010; Ali et al., 2012).

In group $\mathrm{VI}$ which were given metformin should be able to reduce blood sugar levels significantly but in this study blood sugar levels increased although not significantly ( $p$-value= 0.442; $\mathrm{Cl}$ 95\%). Based on literature study, it is known that this condition can occur in connection with the nature of the effects of the drug metformin as a time-dependent drug. The hypoglycemic effect of metformin occurs after 28 days of use (Erejuwa et al., 2011). In this study, metformin was given for 21 days so that it had not reached the time of effective use to cause hypoglycemic effects.

In this study it can also be seen that the effect of the extract of $P$. macrocarpa pericarps on blood sugar levels of diabetic rat models shows as a 
dose-dependent drug, i.e the higher the dose the stronger the effect. The dose of $300 \mathrm{mg} / 200 \mathrm{~g} \mathrm{BW} /$ day as the highest dose used in this study showed the highest effectiveness compared to other groups, as shown in Table 1. However, these findings need to be confirmed through further research using a higher dose range and evaluation of possible toxic effects.

The repairing of the Langerhans islets was determined based on the average area of the Langerhans island in each study group. The area of the pancreatic Langerhans islets was measured using a microscope connected to CellSense Standard ${ }^{\circledR}$ software on histology slides with hematoxylin eosin (HE) staining at 200x magnification. The area of the Langerhans islets measured as shown in Figure 2.

In general, the largest average area of the Langerhans islets was found at group I which is a healthy control group $\left(7473.20 \pm 420.6 \mu \mathrm{m}^{2}\right)$ as shown in Figure 3 . In the research group the fruit extracts $P$. macrocarpa, the largest average area of Langerhans is in group $\mathrm{V}$ $\left(3938.60 \pm 572.42 \mu \mathrm{m}^{2}\right)$ and the smallest was found in group III (1944.75 \pm 213.15 $\mu \mathrm{m}^{2}$ ) while the group VI given metformin has an average area of Langerhans islets is $3442.75 \pm 518 \mu \mathrm{m}^{2}$ or smaller than group V.

Statistical analysis showed that there were significant differences of the average area of the Langerhans islets between the study groups $(p=0.000 ; \mathrm{Cl}$ 95\%). Significantly differences of the average area of the Langerhans island were mainly found between group I with all other research groups ( $p$ value $=0.000$; $\mathrm{Cl} 95 \%)$, group II with groups $\mathrm{V}$ and $\mathrm{VI}(\mathrm{p}$ values $=0.000$ and $0.009 ; \mathrm{Cl} 95 \%)$, group III with group $\mathrm{V}$ and $\mathrm{VI}$ ( $\mathrm{p}$ values $=0.000$ and $0.001 ; \mathrm{Cl} 95 \%$ ) and also group IV and $V(p$ values $=0.003 ; \mathrm{Cl} 95 \%)$. The results of this analysis showed that group $V$ which treated with $P$. macrocarpa fruit extract dose of $300 \mathrm{mg} / 200 \mathrm{~g}$ BW/day had the highest effectiveness in repairing cells damage of Langerhans islets compared with other groups and even with group VI treated with metformin.

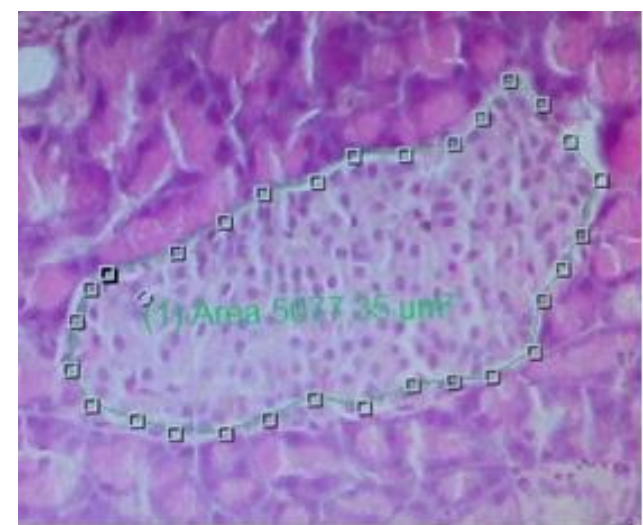

Figure 2. Boundary area measurement area of the Langerhans islets. 


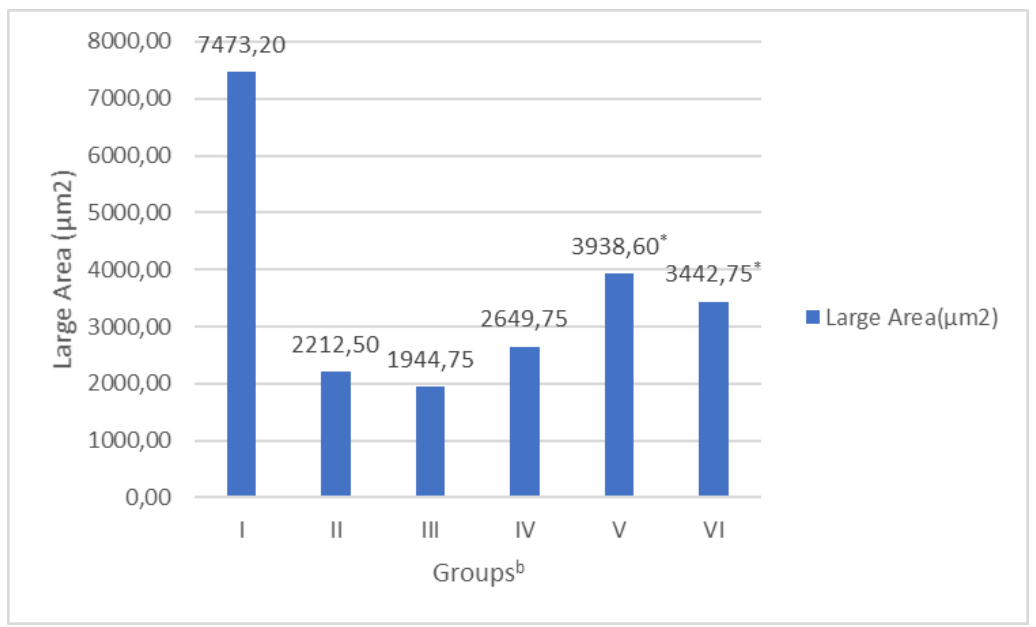

Figure 3. The average area of Langerhans islets in each study group, bone way anova and post hoc LSD test, *p-value $<0.05$ vs group II and III. Group I=healthy control, group II/negative control=diabetic models+aquadest, group III=diabetic modelstethanol extract of $P$. macrocarpa pericarps $200 \mathrm{mg} / 200 \mathrm{~g}$ BW/day, group IV=diabetic models+ethanol extract of $P$. macrocarpa pericarps 250 $\mathrm{mg} / 200 \mathrm{~g}$ BW/day, group $V=$ diabetic models+ethanol extract of $P$. macrocarpa pericarps $300 \mathrm{mg} / 200 \mathrm{~g} \mathrm{BW} /$ day, group $\mathrm{Vl}=$ diabetic models+metformin 150 $\mathrm{mg} / 200 \mathrm{~g}$ BW/day.

The extract of $P$. macrocarpa pericarps has anti-hyperglycemia and antioxidant effects that can reduce blood sugar levels and repairing the damage of Langerhans islets. As it is known that the condition of hyperglycemia can trigger oxidative stress which will result in $\beta$ cell apoptosis and ends with damage to the Langerhans islets. The effects of hypoglycemia and antioxidant of extracts will prevent this condition. The antioxidant effect of flavonoid compounds has been known able to neutralize free radicals that accumulate in cells due to diabetes mellitus, thereby reducing oxidative stress and stopping the destruction of $\beta$ cells in the Langerhans islets. In addition, flavonoids can also stimulate the regeneration process of Langerhans islets (Choi et al., 2009). Whereas the content of other compounds such as benzophenone glycoside derivatives is thought to have the activity of suppressing cell apoptosis mediated by caspase- 3 activation, increasing $\beta$ cell proliferation so that it can repair damaged the Langerhans islets which in this study are shown by its ability to prevent futher damage of the langerhans islets compared to the negative control group (group II) (Oshimi et al., 2008).

The results of this study also prove that metformin can also repairing damage of the Langerhans islets of diabetic rat models, although in this study it was less effective than $P$. macrocarpa fruit extracts. These results are in accordance with the research of 
Murad et al. (2015) which proves that metformin and pioglitazone given with or without combination can provide a better regeneration effect on the Langerhans islets, reduce oxidative stress, inhibit cell apoptosis and increase cell mass in the Langerhans islets on diabetic rat models.

The results of this study also prove that metformin can also repairing damage of the Langerhans islets of diabetic rat models, although in this study it was less effective than $P$. macrocarpa fruit extracts. These results are in accordance with the research of Murad et al. (2015) which proves that metformin and pioglitazone given with or without combination can provide a better regeneration effect on the Langerhans islets, reduce oxidative stress, inhibit cell apoptosis and increase cell mass in the Langerhans islets on diabetic rat models.

However, the results of this study are still incomplete. Although the extract of $P$. macrocarpa pericarps has shown hypoglycemic effects but these effects have not been able to achieve the condition of blood sugar levels and area of the langerhans islets as same as healthy control group. The tendency of pharmacological effects of the extract of $P$. macrocarpa pericarps is dosedependent drug so there is a possibility that effectiveness will increase along with increasing dose. This requires further research with a higher dose range and conducting toxicological tests to identify possible toxic effects.

\section{Conclusion}

The results of this study can be concluded that the extract of $P$. macrocarpa pericarps had a hypoglycemic effect and repaired damage to the Langerhans islets of STZinduced rat pancreas and an increase in dosage showed a tendency to increase the effectiveness.

\section{Acknowledgment}

The authors are sincerely thanks to Ministry of Research, Technology, and Higher Education of the Republic of Indonesia, Jenderal Soedirman University and Faculty of Medicine Jenderal Soedirman University on for providing the facilities to carry out this study, Mumuh Muhidin for technical laboratory assistance in this research.

\section{Reference}

Ali, R.B., Atangwho, I.J., Kaur, N., Abraika, O.S., Ahmad, M., Mahmud, R., Asmawi, M.Z. 2012. Bioassay-guided antidiabetic study of Phaleria macrocarpa fruit extract. Molecules, 17:4986-5002.

Arjadi, F., Priyo., S. 2010. Regenerasi sel pulau Langerhans pada tikus putih (Rattus norvegicus) diabetes yang diberi rebusan daging mahkota dewa (Phaleria macrocarp (Scheff.) Boerl.). Sains Medika, 2(2):117-126.

Bjornstad, P., Schäfer, M., Truong, U., Cree-Green, M., Pyle, L., Baumgartner, A., Reyes, Y.G., Maniatis, A., Nayak, S., Wadwa, R.P., Browne, L.P., Reusch, J.E.B., 
Nadeau, K.J. 2018. Metformin improves insulin sensitivity and vascular health in youth with type 1 diabetes mellitus: randomized controlled trial. Circulation, 138:2895-2907.

Choi, S.J., Kang, S.W., Li, J., Kim, J.L., Bae, J.Y., Kim, D.S., Shin, S.Y., Jun, J.G., Wang, M.H., Kang, Y.H. 2009. Blockade of oxidized LDLtriggered endothelial apoptosis by quercetin and rutin through differential signaling pathways involving. Journal of Agricultural and Food Chemistry, 57(5):20792086.

Cree-Green, M., Bergman, B.C., Cengiz, E., Fox, L.A., Hannon, T.S., Miller, K., Nathan, B., Pyle, L., Kahn, D., Tansey, M., Tichy, E., Tsalikian, E., Libman, I., Nadeau, K.J. 2019. Metformin improves peripheral insulin sensitivity in youth with type 1 diabetes. The Journal of Clinical Endocrinology \& Metabolism, 104(8):3265-3278.

Erejuwa, O.O., Sulaiman, S.A., Wahab, M.S., Salam, S.K.N., Salleh, M.S.M., Gurtu, S.L. 2011. Comparison of antioxidant effects of honey, glibenclamide, metformin, and their combinations in the kidneys of streptozotocin induced diabetic rats. International Journal of Molecular Sciences, 12:829-843.

Guido, M., Alessandra, M., Gavino, F. 2011. Chronic viral hepatitis: the histology report. Digestive and Liver Disease, 43S:331-343.

Hendra, R., Ahmad, S., Oskoueian, E., Sukari, A., Shukor, Y. 2011.
Antioxidant, anti-inflammatory and cytotoxicity of Phaleria macrocarpa (Boerl.) Scheff fruit. $B M C$ Complementary and Alternative Medicine, 11:110119.

International Diabetes Federation. 2013. IDF Diabetes Atlas. $6^{\text {th }}$ Edition. Brussels: IDF Press.

Jones, H.B., Nugent, D., Jenkins, R. 2010. Variation in characteristics of islets of Langerhans in insulinresistant, diabetic and nondiabetic-rat strains. Journal compilation, 91:288-301.

Judiono, Purwaningsih, E., Djokomoeljanto, R.R.J., Hadisaputro, S. 2009. Pengaruh pemberian kefir bening terhadap kadar glukosa darah pada tikus wistar hiperglikemia yang diinduksi streptozotocin (STZ). Penelitian Gizi dan Makanan, 32(2):131-138.

Kumar, S., Narwal, S., Kumar, V., Prakash, O. 2011. $\alpha$-Glucosidase inhibitors from plants: a natural approach to treat diabetes. Pharmacognosy Reviews, 5(9):19-29.

Murad, H.A.S., Hamid, A.S., Gamal, S.A., May, A.A., Soad, S.A. 2015. Effect of metformin and pioglitazone on $\beta$-catenin and biochemical markers in sitaglipin-induced pancreatitis in diabetic rats. International Journal of Diabetes in Developing Countries, 35:332339. 
Novelli, M., Canistro, D., Martano, M., Funel, N., Sapone, A., Melega, S., Masini, M., de Tata, V., Pippa, A., Cecilia, V., Campani, D., de Siena, R., Soleti, A., Paolini, M., Masiello, P. 2014. Anti-diabetic properties of a non-conventional radical scavanger, as compared to pioglitazone and exendin-4, in streptozotocin-nicotinamide diabetic mice. European Journal of Pharmacology, 729:37-44.

Oshimi, S., Zaima, K., Matsuno, Y., Hirasawa, Y., lizuka, T., Studiawan, H., Indrayanto, G., Zaini, N.C., Morita, H. 2008. Studies on the constituens from the fruits of Phaleria macrocarpa. Journal National Medicine, 62:207-210.

Salman, Z.K., Refaat, R., Selima, E., El Sarha, A., Ismail, M.A. 2013. The combined effect of metformin and L-cysteine on inflammation, oxidative stress and insulin resistance in streptozotocininduced type 2 diabetes in rats. European Journal of Pharmacology, 714:448-455.

Sihombing, Marice., Sulistyowati, Tuminah. 2011. Perubahan nilai hematologi, biokimia darah, bobot organ dan bobot badan tikus pada umur berbeda. Jurnal Veteriner, 12(1):58-64.

Singh, J. 2008. Maceration, percolation and infusion techniques for the extraction of medicinal and aromatic plants. In Extraction Technologies for Medicinal and Aromatic Plants. Eds Handa, S.S.,
Khanuja, S.P.S., Longo, G., Rakesh, D.D. Italy: International Center for Science and High Technology.

Suarsana, I.N., Priosoeryanto, B.P., Bintang, M., Wresdiyanti, T. 2010. Profile of blood glucose and ultrastucture of beta cells pancreatic islet in alloxan compound induced rats. Indonesian Journal of Animal and Veterinary Science, 15(2):118-123.

Subiyono, M., Martsiningsih, A., Gabrela, D. 2016. Gambaran kadar glukosa darah metode GOD-PAP (Glucose Oxsidase-Peroxidase Aminoantypirin) sampel serum dan plasma EDTA (Etilen Diamin Tetra Acetat). Jurnal Teknologi Laboratorium, 5(1):45-48.

Sugiwati, S., Kardono, L.B.S., Bintang, M. 2006. A-glukosidase inhibitor activity and hypoglycemic effect of Phaleria macrocarpa fruit pericarp extracts by oral administration to rats. Journal of Applied Sciences, 6(10):23122316.

World Health Organization. 2016. Global Report on Diabetes. http://www.who.int/about/licen sing/copyright_form/index.html. Data diakses pada 3 November 2020.

Zhou, J., Massey, S., Story, D., Li, L. 2018. Metformin: an old drug with new applications. International Journal of Molecular Sciences, 2863(19):1-15. 